\title{
SEASONAL VARIATIONS OF TRACE METALS IN THE GROUNDWATER SAMPLES OF HARIHARA TALUK, DAVANGERE DISTRICT, KARNATAKA
}

\author{
S. Thirumala ${ }^{1}$ and B. R. Kiran ${ }^{2, *}$ \\ ${ }^{1}$ Department of Environmental Science, Government First Grade College \& P.G. Center, Near \\ Anubav Mantapa, Davanagere-577004, Karnataka. \\ ${ }^{2}$ Research \& Teaching Assistant in Environmental Science, DDE, Kuvempu University, \\ Shankaraghatta-577451, Karnataka \\ *E-mail: drbrk2003@gmail.com
}

\begin{abstract}
The present examination manages the appraisal of trace metals, for example, iron, zinc, copper, lead, chromium, cadmium and manganese in the groundwater samples of the Harihara taluk of Karnataka territory brought about by natural just as anthropogenic activities. The outcomes are contrasted and the BIS and WHO guidelines for consumable water to distinguish the areas which are not according to norms.

Keywords: Groundwater, Harihar Taluk, Trace Metals, Drinking Water Standards
\end{abstract}

(c) RASĀYAN. All rights reserved

\section{INTRODUCTION}

Water is one of the fundamental necessities of individuals. Groundwater is a significant wellspring of water supply all through the world. The groundwater quality is ordinarily portrayed by various physicochemical attributes. These parameters change generally because of the different kinds of contamination, regular variance, groundwater extraction, and so forth. Consequently, constant checking on groundwater ends up required so as to limit the groundwater contamination and have control over the contamination caused operators. The amount and the appropriateness of groundwater for human utilization and for water system are controlled by its physical, chemical and bacteriological properties. ${ }^{1,2}$

Groundwater use in the water system, ventures and local use keeps on expanding where the lasting surface water source is missing. The modernization, over abuse, quick industrialization and expanded populace has lead to the quick debasement of our condition. To fulfill the rising need it is basic to perceive the new water assets and furthermore to discover therapeutic techniques for the development of water quality. Modern waste and the metropolitan strong waste have developed as one of the main sources of contamination of surface and groundwater. In numerous pieces of the nation, accessible water is rendered non-consumable on account of the nearness of overwhelming metal in overabundance. The circumstance gets intensified amid the late spring season because of water shortage and downpour water release ${ }^{3,4}$.

Groundwater quality is corrupting because of builds human residence and business practice. The main objectives of the present study are to explore some trace metal parameters of the groundwater of Harihara taluk, Karnataka. No work has been done in the present investigation region henceforth the examination was embraced.

\section{EXPERIMENTAL}

\section{Study Area}

Harihara is one of the taluk headquarters, arranged $18 \mathrm{~km}$ far from Davangere District of Karnataka. Harihara taluk is situated between $14^{\circ} 30^{\prime} \mathrm{N}$ latitude and $75^{\circ} 53^{\prime} \mathrm{E}$ longitude. Overall, the district has and

Rasayan J. Chem., 12(3), 1195-1202(2019)

http://dx.doi.org/10.31788/RJC.2019.1235271

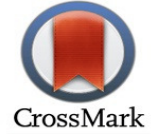


dry and wetland additionally rough regions with a normal height of $700 \mathrm{mts}$ above MSL. Harihara taluk has a topographical region of 995.45 Sq.kms. The taluk goes under a stone and gneissic development which is by and large called as "hard rock territory". Be that as it may, greenstone belt comprising of chlorite-schist, mica schist alongside earth developments have been seen in the hard rock arrangements of this area. The normal precipitation of this territory is $579.02 \mathrm{~mm}$ and it gets the significant precipitation from South-West rains and halfway from North -East monsoon.

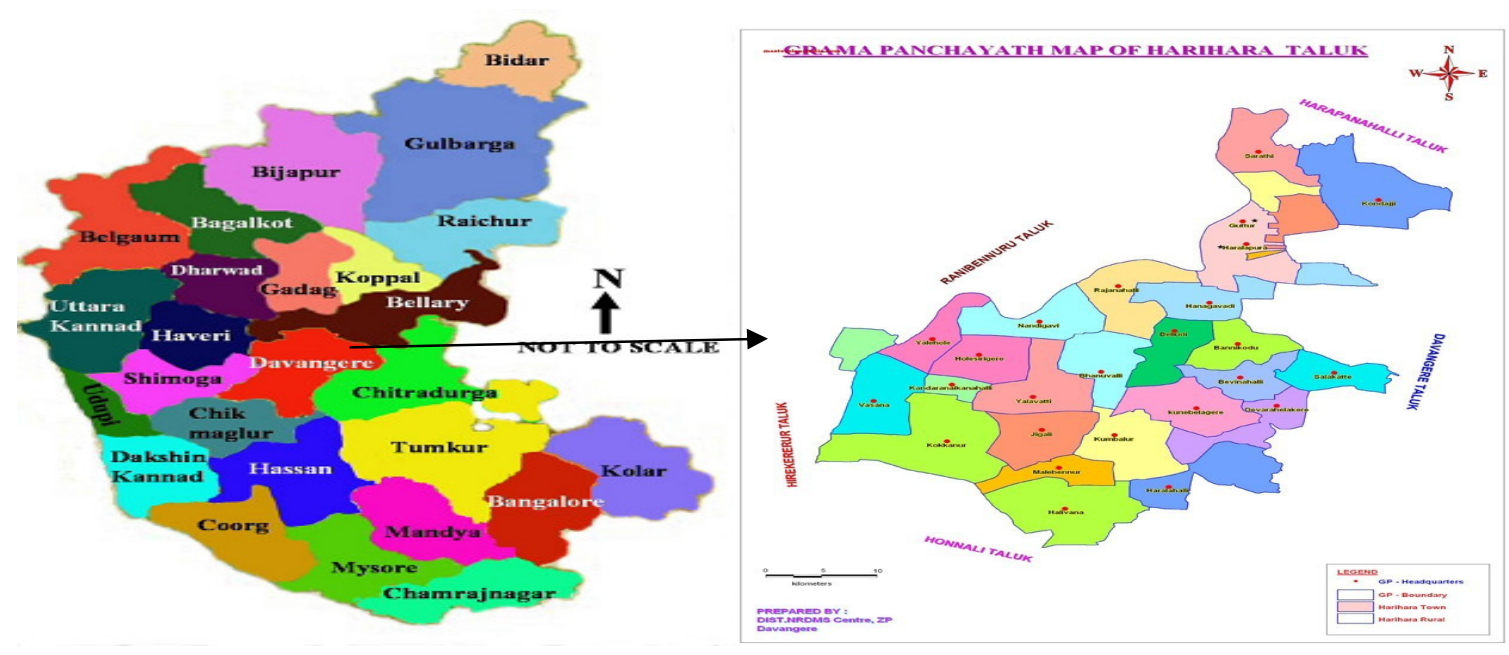

Fig.1:Study Area

(Source:https://www.go2india.in/karnataka/index.phpwww.masterplansindia.com/karnataka/hariharataluk-gramapanchayth-map)

Table- 1: Locations of Ground Water in Harihara Taluk

\section{Water Analysis}

\begin{tabular}{c|c}
\hline Samples & Locations \\
\hline S1 & Amaravathi (CT) \\
\hline S2 & Bannikodu \\
\hline S3 & Bevinahalli \\
\hline S4 & Budihalu \\
\hline S5 & Devarabelakere \\
\hline S6 & Govinahalu \\
\hline S7 & Hanagawadi \\
\hline S8 & Harihar (Rural) \\
\hline S9 & Doggalli \\
\hline S10 & Kenchanahalli \\
\hline S11 & Kondajji \\
\hline S12 & Malebennur \\
\hline S13 & Nandigavi \\
\hline S14 & Vasana \\
\hline S15 & Vaderahalli \\
\hline S16 & Sarathi \\
\hline S17 & Rajanahalli \\
\hline S18 & Nittur \\
\hline S19 & Nagenahalli \\
\hline S20 & Nandi Tavare \\
\hline
\end{tabular}

The assessment of trace metal concentration in ground water of Harihara taluk, Karnataka was carried out for 3 seasons (Monsoon, Post monsoon and Premonsoon) in the year 2016. A total of 20 water samples were selected from identified borewells and the water samples were collected in sterilized black colored carbuoys of 2 litres capacity. The preservation and the analysis of trace metals in water samples 
RASĀYAN J. Chem.

Vol. 12 | No. 3 |1195 - 1202| July - September | 2019

are made as prescribed in the standard methods of $\mathrm{APHA}^{5}$ by using Atomic Absorptions Spectrophotometer.

The one-way or one-factor-ANOVA test for independent measures is calculated for trace metals during three seasons to compare the means of three or more independent samples (treatments) simultaneously.

\section{RESULTS AND DISCUSSION}

Water is valuable for each living life forms on this planet. In the present situation, spontaneous urbanization, fast industrialization and aimless utilization of counterfeit synthetics reason for substantial and shifted contamination in sea-going conditions prompting decay of water quality and consumption of fauna. Without the learning of water science, it is hard to comprehend the organic wonder completely, in light of the fact that the science of water uncovers much about digestion of the environment and clarifies the general hydro-natural interrelationship ${ }^{6-8}$.

The present findings of the study are summarized in Figures- 2 to 4 and Table- 2 depicts the drinking water standards of trace metals as per BIS standards.

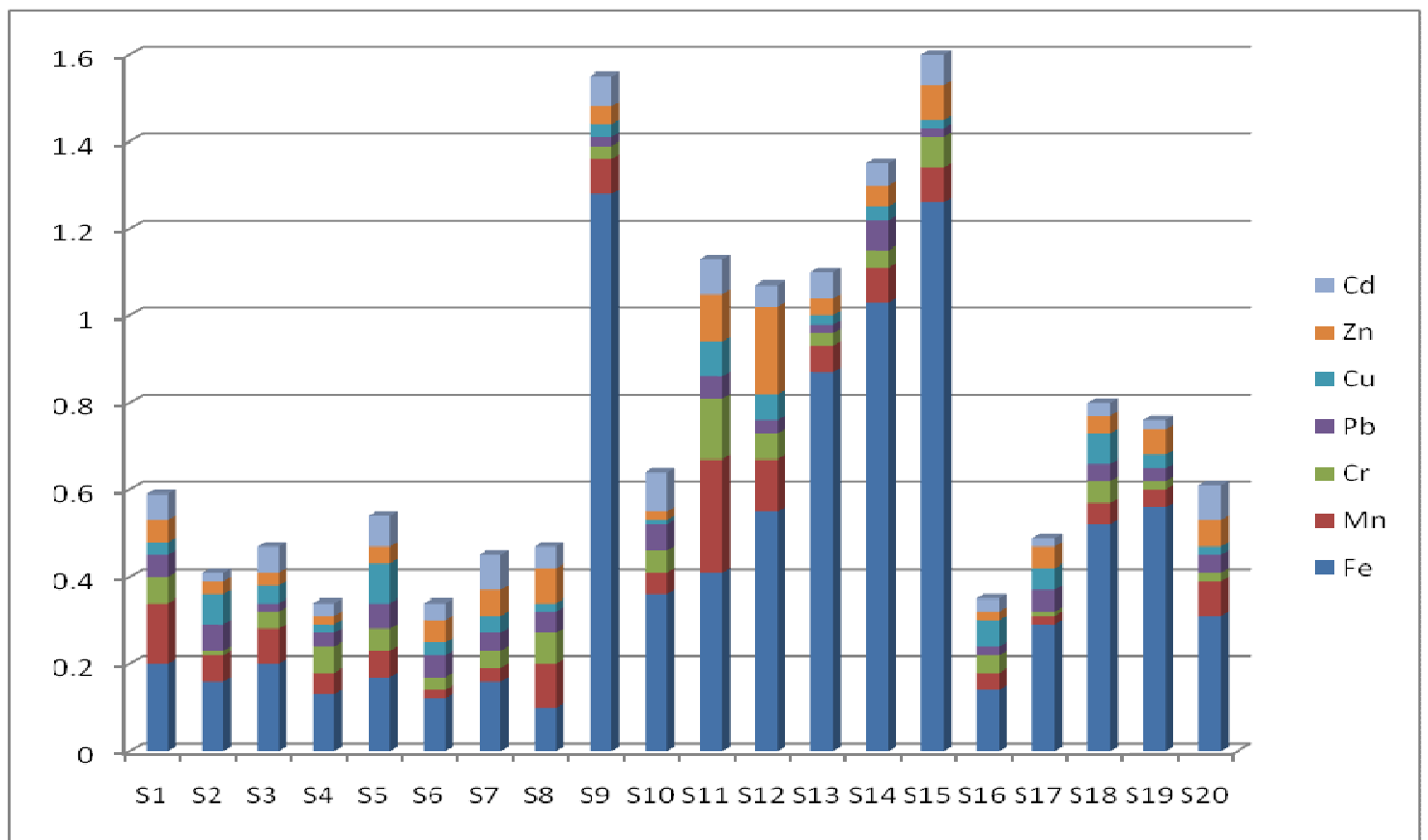

Fig.- 2 : Trace Metal Concentration(mg/l) of Ground Water Samples During Pre-Monsoon Season (April-2016) from Harihara Taluk.

Iron is the most inexhaustible component in the world's covering. It happens for the most part as a ferrous and ferric state.Usually, iron happening in groundwater is as ferric hydroxide, in fixation under $0.5 \mathrm{mg} / \mathrm{l}$. The iron insufficiency causes an illness called "Anemia" and delayed utilization of drinking water with a high grouping of iron may prompt liver ailment called haemosiderosis. ${ }^{9,10}$

The iron substance is most extreme $(1.28 \mathrm{mg} / \mathrm{l})$ in the course of pre-monsoon season at site $\mathrm{S} 9$ and least among post-monsoon season in site S5. The estimations of iron were inside the admissible furthest reaches of BIS drinking water norms in every one of the destinations aside from S9 and S19. The BIS adequate cutoff for iron is $1 \mathrm{mg} / \mathrm{l}$.

Manganese happens in surface water and groundwater sources and in soils that may dissolve into these waters. Be that as it may, human exercises are additionally in charge of a great part of the manganese pollution in water in certain regions It ought to be noticed that the nearness of manganese in drinkingwater will be objectionable to consumers if the manganese is saved in water mains and causes water staining. Focuses underneath $0.05 \mathrm{mg} / \mathrm{l}$ are generally worthy to customers ${ }^{11}$. The manganese content is greatest $(0.29 \mathrm{mg} / \mathrm{l})$ amid post-monsoon season at site $\mathrm{S}-11$ and least amid monsoon season in site $\mathrm{S}-4$. 
The estimations of Mn were inside the reasonable furthest reaches of BIS drinking water measures in every one of the destinations aside from $\mathrm{S}-11$. The $\mathrm{WHO}^{18}$ worthy farthest point for manganese is 0.05 $\mathrm{mg} / \mathrm{l}$.

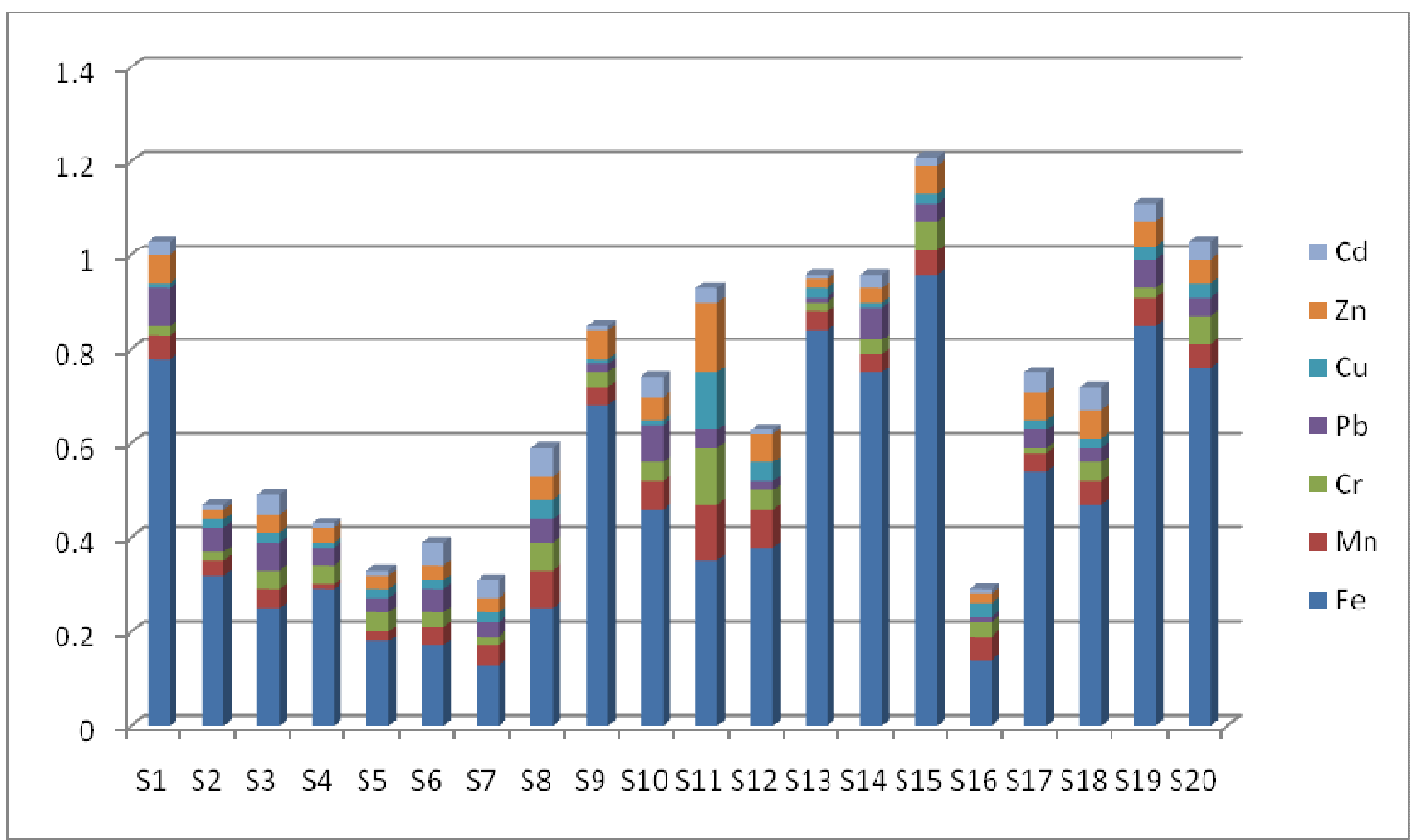

Fig.-3 : Trace Metal Concentration (mg/l) of Ground Water Samples During Monsoon Season (August 2016) from Harihara Taluk.

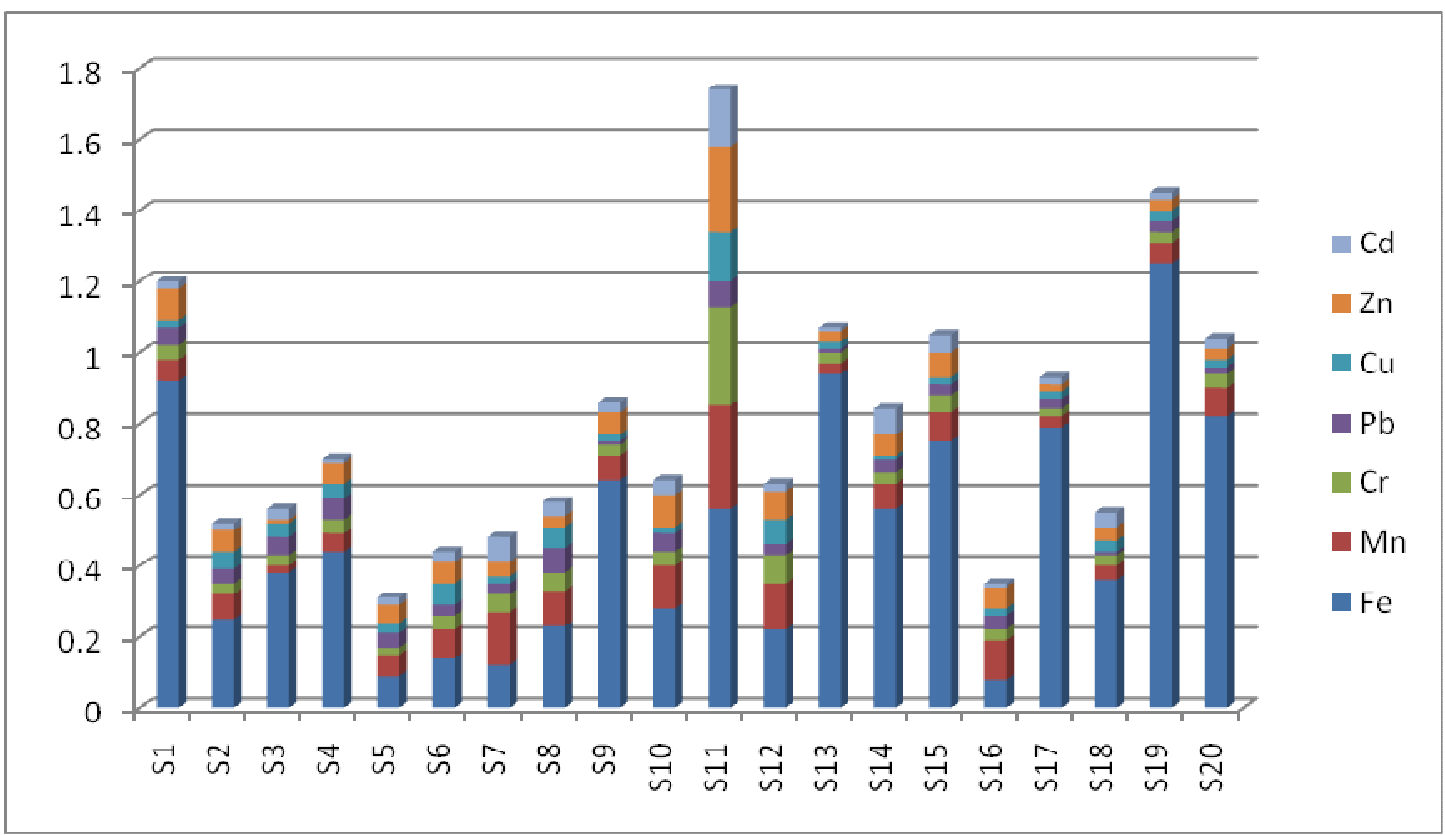

Fig.-4 : Trace Metal Concentration(mg/l) of Ground Water Samples During Post Monsoon Season (December 2016) from Harihara Taluk.

Chromium is a fundamental micronutrient for creatures and plants. Chromium is considered as a relatively organic and contamination importance merciful. For the most part, the characteristic substance of chromium in drinking water is extremely low going 0.01 to $0.05 \mathrm{mg} / \mathrm{l}$ aside from districts with considerable chromium stores ${ }^{12}$. In the present examinations, the chromium fixation is above admissible farthest point in every one of the seasons at site S11. Be that as it may, the convergence of chromium 
wherever recorded is well inside the points of confinement of drinking water gauges in residual locales as recommended by BIS and WHO.

Lead is a bothersome trace metal and it hinders a few key proteins engaged with the general procedure of haemo-synthesis whereby metabolic transitional gathers ${ }^{13}$. The examination uncovered that the centralization of lead is underneath the perceptible dimension in a large portion of the borewell samples with the exception of S-10,S-11 and S-14 sites. However, the concentration of lead observed is within the safe limit of $\mathrm{BIS}^{14}$.

Table- 2 : Drinking Water Quality Standards for Trace Metals ${ }^{14}$

\begin{tabular}{l|c|c}
\hline \multicolumn{1}{c|}{$\begin{array}{c}\text { Parameter BIS } \\
\text { (2012) }\end{array}$} & $\begin{array}{c}\text { Acceptable } \\
\text { limit(mg/l) }\end{array}$ & $\begin{array}{c}\text { Permissible } \\
\text { limit(mg/l) }\end{array}$ \\
\hline Iron & 0.3 & No Relaxation \\
\hline Chromium & 0.05 & 0.05 \\
\hline Copper & 0.05 & 1.5 \\
\hline Cadmium & 0.003 & No Relaxation \\
\hline Lead & 0.01 & No Relaxation \\
\hline Nickel & 0.02 & No Relaxation \\
\hline Arsenic & -- & 0.05 \\
\hline Zinc & 5 & 15 \\
\hline Mercury & 0.001 & No Relaxation \\
\hline Manganese & 0.1 & 0.3 \\
\hline
\end{tabular}

Table- 3 : One way- ANOVA for Trace Metals( $\mathrm{Fe}, \mathrm{Mn}, \mathrm{Cr}, \mathrm{Pb}, \mathrm{Cu})$ concentration of Ground Water Samples During Pre-Monsoon Season from Harihara Taluk.

\begin{tabular}{|c|c|c|c|c|c|c|c|}
\hline & \multicolumn{7}{|c|}{ Treatments } \\
\hline & 1 & 2 & \multicolumn{2}{|c|}{3} & 4 & 5 & Total \\
\hline $\mathrm{N}$ & 20 & 20 & \multicolumn{2}{|c|}{20} & 20 & 20 & 100 \\
\hline$\sum X$ & 8.81 & 1.49 & \multicolumn{2}{|c|}{0.92} & 0.81 & 0.82 & 12.85 \\
\hline Mean & 0.4405 & 0.0745 & \multicolumn{2}{|c|}{0.046} & 0.0405 & 0.041 & 0.129 \\
\hline$\sum X^{2}$ & 6.6401 & 0.1659 & \multicolumn{2}{|c|}{0.0578} & 0.0377 & 0.0438 & 6.9453 \\
\hline Std.Dev. & 0.3811 & 0.0538 & \multicolumn{2}{|c|}{0.0285} & 0.0161 & 0.0231 & 0.2312 \\
\hline \multicolumn{2}{|c|}{ Source } & \multicolumn{2}{|c|}{ SS } & df & \multicolumn{2}{|l|}{ MS } & \\
\hline \multicolumn{2}{|c|}{ Between-metals } & \multicolumn{2}{|c|}{2.4493} & 4 & \multicolumn{2}{|l|}{0.6123} & $F=20.44879$ \\
\hline \multicolumn{2}{|c|}{ Within-metals } & \multicolumn{2}{|c|}{2.8447} & 95 & \multicolumn{2}{|l|}{0.0299} & \\
\hline \multicolumn{2}{|c|}{ Total } & \multicolumn{2}{|c|}{5.2941} & & & & \\
\hline
\end{tabular}

The f-ratio value is 20.44879. The p-value is $<.00001$. The result is significant at $\mathrm{p}<.05$. 
RASĀYAN J. Chem.

Vol. 12 | No. 3 |1195 - 1202| July - September | 2019

Copper is one of the basic components for people. It is broadly circulated metal in nature. It very well may be available in the oceanic condition in three structures to be specifically dissolvable, colloidal and particulate. It is found in less amount as a basic component for living beings. The abundance of copper in the human body is poisonous and causes hypertension and produces obsessive changes in cerebrum tissues. Over the top ingestion of copper is in charge of explicit infection of the bone ${ }^{15}$.

Copper levels is greatest $(0.14 \mathrm{mg} / \mathrm{l})$ in the course of the post-monsoon season at site $\mathrm{S} 11$ and least in every one of the seasons in the greater part of the destinations. The estimations of Copper were inside the reasonable furthest reaches of BIS drinking water benchmarks with the exception of at site S11. The BIS allowable point of confinement for copper is $0.05 \mathrm{mg} / \mathrm{l}$.

Table -4 : One way- ANOVA for Trace Metals( $\mathrm{Cr}, \mathrm{Pb}, \mathrm{Cu}, \mathrm{Zn}, \mathrm{Cd})$ concentration of Ground Water Samples During Monsoon Season from Harihara Taluk.

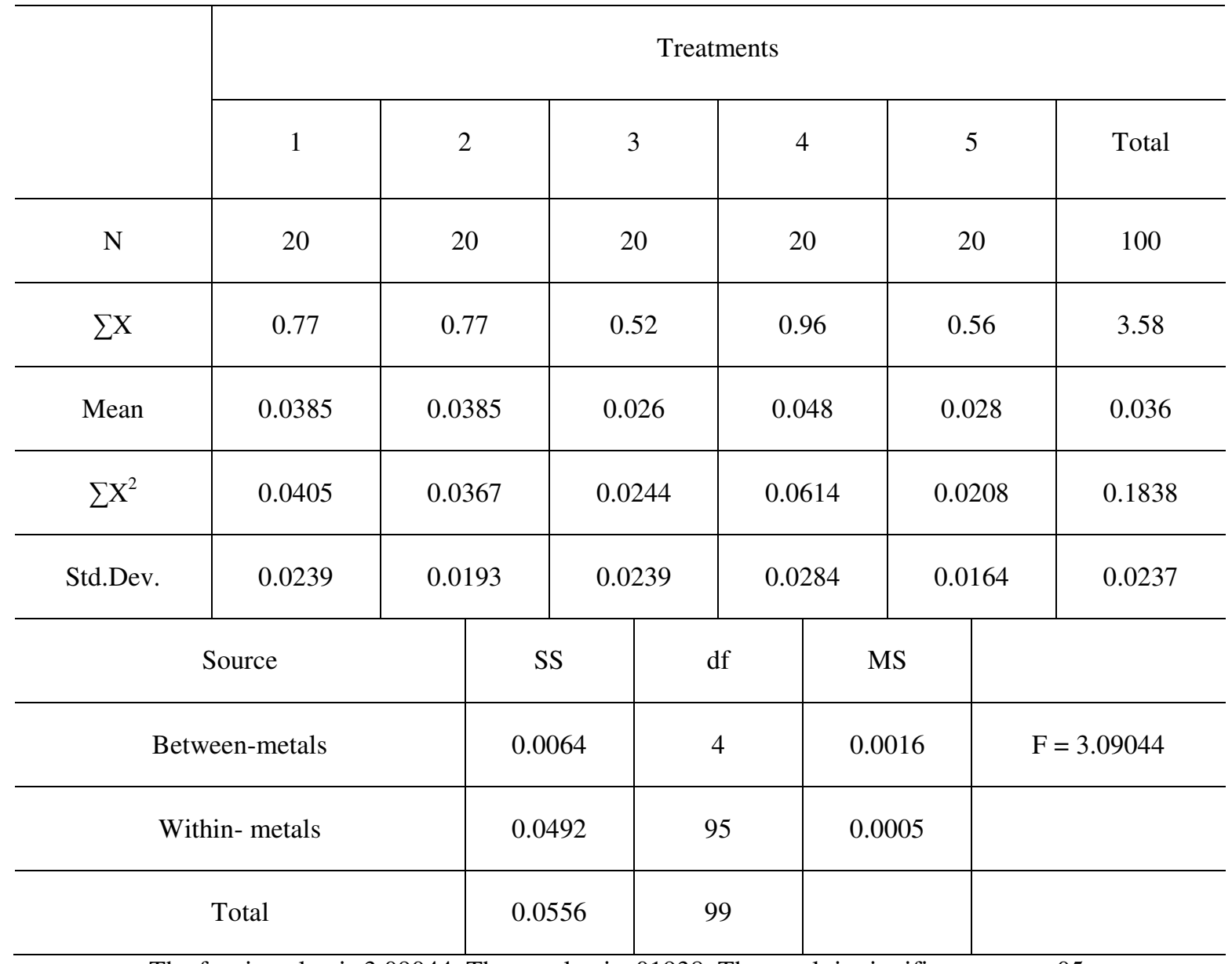

The f-ratio value is 3.09044. The $\mathrm{p}$-value is .01938 . The result is significant at $\mathrm{p}<.05$.

Zinc assume an imperative job in the physiological and metabolic procedure of numerous living beings. All things considered, at higher fixation, zinc is lethal to living beings. It assumes a significant job in protein union. Zinc is a metal which indicates genuinely low focus in surface water, which is because of its confined portability from the spot of shake enduring or from the normal sources ${ }^{14}$. The reasonable breaking point of zinc in water is $0.5 \mathrm{mg} / \mathrm{l}$. The values of zinc are shown within the limit of drinking water standard in all the seasons as well as in all the sites.

Cadmium isn't a fundamental non-valuable component known to have a harmful potential. The centralization of cadmium in the lithosphere is low. It ordinarily ranges from $1 \times 10^{-4}$ to $2 \times 10^{-4} \mathrm{mg} / \mathrm{l}$. The primary sources of cadmium are modern exercises as the metal generally utilized in electroplating, shades, plastic, balances out and battery businesses. Cadmium is profoundly poisonous and in charge of a few instances of harming through nourishment. Little amounts of cadmium cause antagonistic changes in 
the conduits of the human kidney. It replaces zinc biochemically and causes hypertension, kidney harm and so on. Cadmium harming causes an ailment called Itai-itai. Cadmium concentrations in groundwater of the study area are highest during post-monsoon with $0.16 \mathrm{mg} / \mathrm{l}$ at site $\mathrm{S} 11$ and lowest with $0.01 \mathrm{mg} / \mathrm{l}$ in most of the sites in all the seasons. Nevertheless, cadmium in low concentration is quite toxic to human health ${ }^{16}$.

One-way ANOVA test for trace metals depicted F-ratio values during pre-monsoon, monsoon and postmonsoon seasons are 20.44879,3.09044 and 31.02266 separately and the outcome is critical at $\mathrm{p}<.05$ (Tables 3-5).

Table- 5 : One way- ANOVA for Trace Metals(Fe,Mn,Cr,Zn,Cd ) concentration of Ground Water Samples During Post-Monsoon Season from Harihara Taluk.

\begin{tabular}{|c|c|c|c|c|c|c|}
\hline & \multicolumn{6}{|c|}{ Treatments } \\
\hline & 1 & 2 & \multicolumn{2}{|c|}{3} & 5 & Total \\
\hline $\mathrm{N}$ & 20 & 20 & \multicolumn{2}{|c|}{20} & 20 & 100 \\
\hline$\sum X$ & 9.82 & 1.7 & \multicolumn{2}{|c|}{0.99} & 0.74 & 14.46 \\
\hline Mean & 0.491 & 0.085 & \multicolumn{2}{|c|}{0.0495} & 0.037 & 0.145 \\
\hline$\sum X^{2}$ & 6.9466 & 0.211 & \multicolumn{2}{|c|}{0.1083} & 0.049 & 7.4314 \\
\hline Std.Dev. & 0.3344 & 0.0592 & \multicolumn{2}{|c|}{0.0559} & 0.0337 & 0.2323 \\
\hline \multicolumn{2}{|c|}{ Source } & \multicolumn{2}{|c|}{ SS } & $\mathrm{df}$ & MS & \\
\hline \multicolumn{2}{|c|}{ Between- metals } & \multicolumn{2}{|c|}{3.0248} & 4 & 0.7562 & $\mathrm{~F}=31.02266$ \\
\hline \multicolumn{2}{|c|}{ Within- metals } & \multicolumn{2}{|c|}{2.3157} & 95 & 0.0244 & \\
\hline \multicolumn{2}{|c|}{ Total } & \multicolumn{2}{|c|}{5.3405} & & & \\
\hline
\end{tabular}

The f-ratio value is 31.02266. The $\mathrm{p}$-value is $<.00001$. The result is significant at $\mathrm{p}<.05$.

\section{CONCLUSION}

In the present investigation, the trace metal concentration is well within the permissible limits in all the sites prescribed by the BIS standards except in sites S9, S10, S11, S14, S15, and S18. In any case, right now conveyed research study should give a progressively exact answer on the impact of the geomorphological condition than anthropogenic exercises in the analyzed groundwater tests of the examination zone. Nearby topographical settings may bolster the expanding grouping of water quality attributes in groundwater. The components like the moderate course, longer time of contact among aquifer and water, dissolving of minerals at the season of enduring, private time, waste example and surface water interface. The porosity of the dirt and rock additionally changes the attributes of the groundwater. $^{17}$

\section{REFERENCES}

1. R. Mangukiya, T. Bhattacharya and S. Chakraborty, International Research Journal of Environment Sciences, 1(4) 14(2012). 
RASĀYAN J. Chem.

Vol. 12 | No. 3 |1195 - 1202| July - September | 2019

2. G. R. Kalpana, D. P. Nagarajappa, K. M. Sham Sundar and B. Suresh, International Journal of Engineering and Innovative Technology 3(12) 90(2014).

3. Jai M. Paul, V.S. Arya, Jesteena George, K.J. Reji and K. S. Sumitha, International Journal of Engineering Science Invention 3 ( 4) 21-28,(2014).

4. S. Thirumala and B. R. Kiran, International Journal of ChemTech Research, 10(7) 99-104,(2017).

5. APHA, Standard Methods of the Examination of Water and Wastewater (18th edn), American Public Health Association, New York 11-20,(1998).

6. U. Deshmukh, and N.E Ambore, J. Aqua. Biol., 21(2), 93 (2006).

7. R. Patil, Anil, and S. Lohar Prakash , J. Aqua. Biol., 24(2), 1 ( 2009).

8. B. R. Kiran, Rasayan Journal of Chemistry, 3(4) 671(2010),

9. Rajgopal, Groundwater quality assessment for public policy in India. 1st Annual report. Department of geography, IOWA University, IOWA 10-11,(1984).

10. B. Rajappa , S. Manjappa and E. T. Puttaiah, Contemporary Engineering Sciences 3(4)183(2010).

11. WHO, Manganese in Drinking-W ater, Background Document for Development of WHO Guidelines for Drinking-water Quality (2011).

12. K. H. Wedepohl, Hand book of Geochemistry Ex-Editor, Springer Verleg Berlies Herdelberg. New York 11-15,(1978).

13. N. K. Verma, O. P. Jain and P. K. Shrivastava, Proc. Acad. Environmental Biology, 4(1) 123(1995).

14. BIS, Indian Standard Drinking Water Specifications( Second revision), Bureau of Indian Standards, New Delhi,2-3, (2012).

15. C. R. Krishnamurthy and V. Pushpa, Toxic Metals in the Indian Environment, Tata McGraw Hill Publishing Co. Ltd., New Delhi. 280,(1995).

16. R. N. Mohan, Chopra and G. C. Choudhary, Poll. Res., 17(2) 167(1998)

17. S. Thirumala, International Journal of Innovative Research in Science, Engineering and Technology 3(5) (2014) .

18. WHO. Guidelines for Drinking Water Supply Quantity(2 $2^{\text {nd }}$ edn). I. Recommendations. World Health Organization, Geneva 180- 81,(1993).

[RJC-5271/2019] 